Journal homepage: http://www.journalijar.com
Journal DOI: $10.21474 /$ IJAROI

RESEARCH ARTICLE
INTERNATIONAL JOURNAL

OF ADVANCED RESEARCH

מחיח

ISSN NO. 2320-5407

\title{
Assessment of the radiation exposures during separation of rare earth elements from monazite mineral
}

\author{
${ }^{*}$ Yassin A. Abdel-Razek ${ }^{1}$, Osman. A. Desouky ${ }^{1}$, Ashraf Elshenawy ${ }^{1}$, Amal S. Nasr ${ }^{1}$, Haitham S. Mohmmed ${ }^{2}$ \\ and Anwar A. Elsayed ${ }^{2}$. \\ 1. Nuclear Materials Authority, Cairo, P.O. box 530, El Maady, Egypt. \\ 2. Biophysics Department, Faculty of Science, Cairo University, Giza, Egypt.
}

\section{Manuscript Info \\ Manuscript History: \\ Received: 18 May 2016 \\ Final Accepted: 19 June 2016 \\ Published Online: July 2016 \\ Key words: \\ Monazite, Rare earth elements, \\ Effective dose, U-content, \\ Biokinetic models \\ *Corresponding Author}

Yassin A. Abdel-Razek.

\begin{abstract}
Through the separation of rare earths elements REEs from monazite mineral, radiation exposures occur. This study estimated the values of these radiation exposures. The study was occurred through two different treatments of monazite, $10 \mathrm{~kg}$ of monazite and $10 \mathrm{~kg}$ of monazite with adding $\mathrm{BaCl}$ at the digestion stage. The activity concentration of radon gas varied between 0.81 and $14.4\left(\mathrm{~Bq} / \mathrm{m}^{3}\right)$ with an average of $8.72\left(\mathrm{~Bq} / \mathrm{m}^{3}\right)$ while the activity concentration of thoron gas varied between 56.88 and $114.7\left(\mathrm{~Bq} / \mathrm{m}^{3}\right)$ with an average of $76.14\left(\mathrm{~Bq} / \mathrm{m}^{3}\right)$. Uranium concentration values in the air of the various areas changed from 0.29 to $0.88\left(\mathrm{~Bq} / \mathrm{m}^{3}\right)$ with an average of 0.39 $\left(\mathrm{Bq} / \mathrm{m}^{3}\right)$. The gamma equivalent dose rates varied from 0.11 to $0.21(\mu \mathrm{Sv} / \mathrm{h})$ with average $0.15(\mu \mathrm{Sv} / \mathrm{h})$. The total annual effective dose received by the workers at the the REES project has values from 0.46 to $12.46(\mathrm{mSv})$ with average values of $3.21(\mathrm{mSv})$.

It was concluded that the values of the occupational effective doses are within the dose limits at the different stages of chemical processing of monazite. However, it is recommended to make technical enhancement to reduce the $\mathrm{U}$-content in the air of the REEs hanger.
\end{abstract}

Copy Right, IJAR, 2016,. All rights reserved.

\section{Introduction:-}

Monazite mineral is an important resource of the rare earth elements REEs. These elements are known to have higher potential to be used in several industries [1]. During the separation of the REEs from monazite mineral, radiation exposures arise to the occupational workers due to the existence of the radioactive elements uranium, thorium and their decay chains.

Pillai [2] studied the presence of NORM in the rare earth minerals in varying concentrations is quite often significant enough to result in occupational and environmental radiation exposures during their mining, milling and chemical processing for the extraction of the rare earth elements and compounds. Depending on the monazite concentration in the raw sand, radiation exposures of the order of $0.13-1.00 \mathrm{man} \cdot \mathrm{mSv}$ per tonne are involved in the mining and separation of monazite. The chemical extraction of rare earths from monazite involves occupational radiation exposures in the range $0.30-1.00$ (mean: $0.64 \pm 0.19$ ) man.mSv per ton of rare earths concentrate.

The long-term health effects of exposure to thorium are of interest because of the possible increased use of thorium as an energy source in reactors using 232Th to produce 233U. Mortality is described in a cohort of 3039 men who were employed between 1940 and 1973 at a company involved in the production of thorium and rare earth chemicals from monazite sand. Based on deaths ascertained by the Social Security Administration and mortality rates for U.S. white males, the standardized mortality ratio (SMR) for all causes was 1.05 with $95 \%$ confidence 
limits (95\% CL) of 0.96 and 1.15. Much of the excess mortality was attributable to non-occupational motor vehicle accidents ( $\mathrm{SMR}=1.64 ; 95 \% \mathrm{CL}=1.16$ and 2.23), but $\mathrm{SMRs}$ were also high for lung cancer $(1.44 ; 95 \% \mathrm{CL}=0.98$ and 2.02), pancreatic cancer $(2.01 ; 95 \% \mathrm{CL}=0.92$ and 3.82), and diseases of the respiratory system $(1.31 ; 95 \% \mathrm{CL}=0.92$ and 1.83). In a subgroup of 592 men who worked for at least one year in selected jobs (indicative of highest exposure to thorium and thoron) that was followed up more intensively, the SMR for pancreatic cancer was significantly elevated (i.e. 4.13 ; $95 \%$ confidence limits $=1.34$ and 9.63). The SMR for lung cancer was 1.68 (95\% $\mathrm{CL}=0.81$ and 3.09), while that for respiratory diseases was 1.20 (95\% $\mathrm{CL}=0.52$ and 2.37). Information on smoking habits in a sample of survivors suggested that smoking could have explained at least part of the excess mortality from lung and pancreatic cancer and from diseases of the respiratory system. Continued follow-up of the cohort through morbidity and mortality studies is needed to evaluate further the possible long-term effects of exposure to radioactivity and chemicals in the thorium extraction process [3].

One of the chief problems in industrial radiological health in Brazil concerns 420 people in a plant processing monazite sand, a rare earth mineral containing up to 6 per cent ThO2 and 0.3 per cent U3O8. Costa-Ribeiro evaluated the Radiation hazards associated with ore concentration and chemical treatment were assessed by sampling and measurement of airborne radioactivity, 210Po bioassay in urine and chromosomal analysis in peripheral blood lymphocytes collected from plant personnel. Results showed that $212 \mathrm{~Pb}(\mathrm{t} 1 / 2=10.64 \mathrm{hr})$ airborne concentrations range from 0.002 up to $3.9 \mathrm{pCi} / \mathrm{l}$. A size distribution analysis showed that in 88 per cent of $212 \mathrm{~Pb}-$ bearing aerosols the mean count diameter is below $0.4[\mathrm{mu}] \mathrm{m}$. Calculated values of airborne long-lived activity as 232Th ranged from 6 × 10-6 up to 1 x 10-4 pCi/l. A few workers had a slight increase in the urinary concentration of 210Po, although results did not show a statistically significant difference between these values and those found in control population. Chromosomal analysis revealed a statistically significant difference in the yield of aberrations for the ore mill workers in one of the plant sections, showing the highest airborne $212 \mathrm{~Pb}$ concentration [4].

In India, rare-earth compounds are produced from the beach sand mineral monazite. Caustic digestion of the mineral followed by selective acid extraction is the method used to separate composite rare-earth fraction. The composite rare-earth chloride contains low levels of natural radionuclides and is the starting material for individual rare-earth compounds which have wide applications. Activity concentrations in composite rare-earth compounds such as chlorides, fluorides, carbonates and oxides of $\mathrm{Ce}, \mathrm{Nd}, \mathrm{Pr}, \mathrm{Sm}, \mathrm{Gd}$, etc. are presented in the study. The external gamma exposure rates and airborne activity due to thorium and thoron progeny in the occupational environment are studied. The activity levels in liquid effluent are presented. The potential individual occupational dose is estimated to be $1.9 \mathrm{mSv}$ per annum [5].

\section{Chemical processing of monazite:-}

Rare earths have been obtained from monazite concentrate through digestion with $98 \%$ sulphuric acid at $200-220^{\circ} \mathrm{C}$. The mineral is decomposed exothermically, forming a pasty mixture of sulphates and acid sulphates suspended in phosphoric acid and excess sulphuric acid. The rare earth chloride solution contains small amounts of impurities such as thorium, uranium, lead, iron and radium.. These are removed through a 'deactivation and lead elimination' process. Barium chloride and sodium sulphate or sulphuric acid are added to co-precipitate lead and other heavy metals along with the barium-radium sulphate formed. Later, sodium sulphide is added in excess to precipitate lead as lead sulphide as well as thorium, uranium and iron. The combined precipitates are removed by filtration as a barium sulphate cake containing radium and lead. This residue, which is sometimes referred to as 'mixed cake' or 'mesothorium cake' is reported in one instance to contain 1.07\% thorium, $0.076 \%$ uranium, $27 \%$ barium sulphate and $21 \%$ rare earth phosphate [6,7]. Modifications to the deactivation and lead elimination process, involving multiple deactivation steps and $\mathrm{pH}$ control, have resulted in lower radioactivity levels in the final rare earth chloride product. Multiple deactivation involves further additions of barium chloride and sodium sulphate, resulting in a larger volume of material and, consequently, lower concentrations of radionuclides in the residue as well as in the product [1]. The flow sheet describes the different stages of the process is shown in Fig (1). 


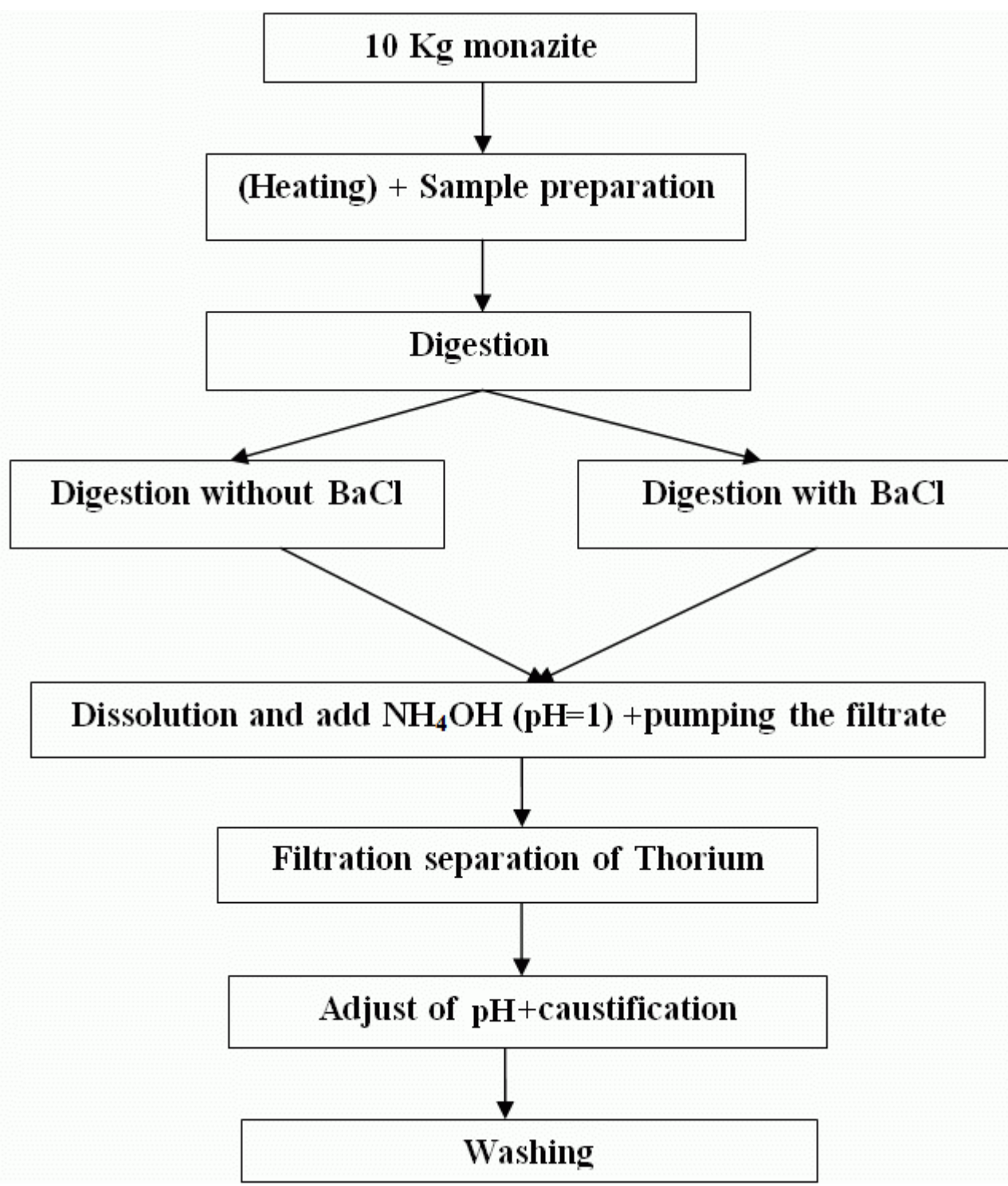

Fig (1): Flow sheet of monazite describes the different stages of the process.

This paper discusses comprehensively the different processes adopted in chemical separation of rare earths from monazite. Estimation of the radiation hazards that occupational workers are exposed to through this processing will be carried out. An approach to minimize the radiation exposures through the chemical extraction of rare earths from monazite will be discussed.

\section{Experimental methods and techniques:-}

The measurements to estimate radiation effective doses were carried out at the hanger of the rare earth elements project (REEs) at the Nuclear Materials Authority (NMA), Egypt. The source of monazite mineral is the beach deposits at Abu Khashaba, northern Nile coast, Egypt. Monazite mineral was concentrated from the beach deposits at the project of concentration and separation of black sands, Egypt.

\section{Measurement of equivalent dose $(\mathrm{H})$ :-}

Measurement of external exposure was estimated by measuring gamma rays using a portable survey meter. Measurements were carried out through the processing of monazite by using survey meter Alnor RDS-100. Direct reading of the equivalent dose rate $(\mathrm{H})(\mu \mathrm{Sv} / \mathrm{h})$ is recorded. 


\section{Estimation of internal exposures:-}

Internal exposure occurs as a result of the inhalation of radon $\mathrm{s}$ and thoron gases in the air and due to the uranium in the dust particles.

- Measurements of radon and thoron concentrations

A SARAD, RTM-1688 device was used to measure the radon and thoron gases concentrations $\mathrm{C}_{\mathrm{Rn}}$ and $\mathrm{C}_{\mathrm{Tn}}$. The device collects an air sample via an internal pump inside its chamber. Concentrations of these gases are displayed on the screen after a desired time after counting the alpha particles emitted from the studied gases and their decay products in the chamber.

- Measurement of the Uranium concentration in the air

Concentrations of uranium in the air dust are measured by collecting an air sample by a sampler on a high efficiency filters for 10 minutes. The $\alpha$-particles will be counted after at least three days so that the short-lived radon and thoron decay products are completely decayed. Uranium content in the air $\mathrm{C}_{\mathrm{U}}$ is calculated by the equation [8]:

$\mathrm{C}_{\mathrm{U}}=2.2 \times 10^{-7}(\mathrm{R}-\mathrm{B})(1+\mathrm{S}) / \mathrm{Etv}$

$\mathrm{C}_{\mathrm{U}}$ : uranium concentration in $\left(\mu \mathrm{Ci} / \mathrm{cm}^{3}\right)$,

$\mathrm{R}: \alpha$ - count rate in (cpm),

E : counting efficiency,

$\mathrm{v}$ : volumetric sampling rate in $(1 / \mathrm{min})$,

$\mathrm{t}$ : sampling time,

B : background (cpm),

$S:$ is the self absorption of the filter $=0.09$.

Results are converted into $\left(\mathrm{Bq} / \mathrm{m}^{3}\right)$.

\section{Results and discussion:-}

During the chemical processing of monazite to extract the REEs there are radiation exposures both externally $(\gamma$ rays) and internally; radon, thoron gases and U-content in the air of working area.

External exposure from gamma rays:-

Effective dose rate is calculated depending on the configuration of exposure to the external $\gamma$-rays. According to ICRP, effective dose rate is calculated as follows [9]:

$\mathbf{E}=\sum \mathbf{H} \mathbf{w}_{\mathbf{T}}$

where $\mathrm{H}$, is the equivalent dose rate and $\mathrm{w}_{\mathrm{T}}$, is the tissue weighting factor for organ or tissue $\mathrm{T}$. Indeed, the configuration of exposure at REEs project represents a whole body exposure. Accordingly, $\sum \mathrm{w}_{\mathrm{T}}$ in equation (2) equals unity. Finally the values of the effective dose rate $\mathrm{E}_{\gamma}(\mu \mathrm{Sv} / \mathrm{h})$ is taken as that of the equivalent dose rate $\mathrm{H}$ $(\mu \mathrm{Sv} / \mathrm{h})$. The annual external effective dose $\mathrm{E}_{\gamma}(\mathrm{mSv} / \mathrm{y})$ received by the occupational workers through processing of monazite assuming 2000 working hours per year is calculated as follows:

$\mathbf{E}_{\mathrm{ex}}(\mathrm{mSv} / \mathrm{y})=\mathbf{E}_{\gamma}(\mu \mathrm{Sv} / \mathrm{h}) \times 2000 \mathrm{~h}$

Table (1) represents the equivalent dose rate $\mathrm{H}(\mu \mathrm{Sv} / \mathrm{h})$ while Table (2) shows the external annual effective doses $\mathrm{E}_{\mathrm{ex}}$ $(\mathrm{mSv} / \mathrm{y})$ at the different stages of chemical processes of monazite. From Table (2), clear that all values of the annual effective dose much below the recommended limit of 20 (mSv/y) [9].

\section{Internal exposure:-}

- Effective dose due to radon and thoron gases:-

Radon has long been recognized as a cause of lung cancer, and was identified as a human lung carcinogen in 1986 by the World Health Organization (WHO) [10,11]. Table (1) represents the activity concentrations of radon and thoron gases. It's clear that the activity concentrations of radon and thoron gases are much below the reported limits of 2000 and $740\left(\mathrm{~Bq} / \mathrm{m}^{3}\right)$ for radon and thoron respectively [12]. This is due to the good ventilation at the hanger of REEs project minimizes the concentrations of these gases at the location.

However, many models were established to estimate the effective doses received by the workers due to the inhalation of radon and thoron gases and their decay products. These models depend on epidemiological and 
physical consideration [12]. However, the range of dose conversion factors for radon various from 6 to 15 $\mathrm{nSv} /\left(\mathrm{Bq} \cdot \mathrm{h} . \mathrm{m}^{-3}\right)$. Given this range of values of the dose conversion factor, the established value of $9 \mathrm{nSv} /\left(\mathrm{Bq} \cdot \mathrm{h} . \mathrm{m}^{-3}\right)$, used in past calculation [13,14] is still considered appropriate for average effective dose calculations [15]. Accordingly, the annual effective doses $\mathrm{E}_{\mathrm{Rn}}$ and $\mathrm{E}_{\mathrm{Tn}}(\mathrm{mSv} / \mathrm{y})$ received by the workers at the REEs project due to the inhalation of radon and thoron gases and their decay products are calculated respectively as follows [15]:

For radon,

$E_{R n}=C_{R n}\left(B q . m^{-3}\right) \times 0.4 \times 2000 h \times 9 n S v\left(B q ~ ~ h^{-3}\right)^{-1}$

For thoron

$\mathrm{E}_{\mathrm{Tn}}=\mathrm{C}_{\mathrm{Tn}}\left(\mathrm{Bq} \cdot \mathrm{m}^{-3}\right) \times 0.03 \times 2000 \mathrm{~h} \times 40 \mathrm{nSv}\left(\mathrm{Bq} \mathrm{h} \mathrm{\textrm {m } ^ { - 3 } ) ^ { - 1 }}\right.$

Table (2) represents the values of the annual effective dose of radon and thoron gases. From the table, all values of both $\mathrm{E}_{\mathrm{Rn}}$ and $\mathrm{E}_{\mathrm{Tn}}$ are much lower than the recommended limit of $20(\mathrm{mSv} / \mathrm{y})$.

\section{- Annual effective dose due to U-content}

Intakes of radionuclides can occur via a number of routes. In the case of occupational exposure the main route of intake is by inhalation; a fraction of material deposited in the respiratory system will, however, be transferred to the throat and swallowed, giving the opportunity for absorption in the gastrointestinal (GI) tract. For intakes by inhalation, the ICRP [16] has described a Human Respiratory Tract Model (HRTM), which has replaced the lung model adopted in Ref. [17]. The HRTM takes account of recent information on the physiology of the lungs and is intended to be applicable to the interpretation of bioassay data as well as the calculation of dose coefficients. It has been used for the calculation of inhalation dose coefficients given in the BSS [18]. The current biokinetic models of the ICRP for systemic activity [19-22] were used for calculating dose coefficients given in the BSS [18] for intakes by inhalation and ingestion. The estimated derived air concentration $\mathrm{DAC}_{\mathrm{U}}$ for $\mathrm{U}-238$ expected to be inhaled by the occupational workers [23]:

$\mathrm{DAC}_{\mathrm{U}}=\mathrm{I}_{\mathrm{U}} / 2000 \times 1.2$

$\mathrm{DAC}_{\mathrm{U}}$ : derived air concentration for $\mathrm{U}-238\left(\mathrm{~Bq} / \mathrm{m}^{3}\right)$,

$\mathrm{I}_{\mathrm{U} . \mathrm{inh} . \mathrm{L}}$ : limit of intake of $\mathrm{U}-238$ which is [23]:

$\mathbf{I}_{\mathbf{U}}=\mathbf{L} / \mathbf{e}(\mathbf{g})_{\mathbf{U}}$

where L: dose limit, 20 (mSv/y),

$\mathrm{e}(\mathrm{g})_{\mathrm{U}}$ : committed effective dose per unit intake $(\mathrm{Sv} / \mathrm{Bq})=5.7 \times 10^{-6}(\mathrm{~Sv} / \mathrm{Bq})[18]$.

Using equations (6) and (7), the derived air concentration of uranium DAC $\mathrm{U}_{\mathrm{U}}$ is $1.46\left(\mathrm{~Bq} / \mathrm{m}^{3}\right)$.

Table (1) represents the uranium content in the air at the location of extraction of REEs from monazite. It is clear that the uranium contents are below the recommended limit of $1.46\left(\mathrm{~Bq} / \mathrm{m}^{3}\right)$. From the table (1), the uranium content in the air at the digestion stage is comparable to the recommended concentration of $1.46\left(\mathrm{~Bq} / \mathrm{m}^{3}\right)$ while it is at the stage of sample preparation lower by one order of magnitude. This is because the time of feeding of the sample into reactor is larger than the time of preparation which allows the dust to get higher concentrations in the air.

The annual effective dose $\mathrm{E}_{\mathrm{U}}(\mathrm{mSv} / \mathrm{y})$ received by the workers at REEs project is calculated as follows:

$\mathrm{E}_{\mathrm{U}}=\mathrm{C}_{\mathrm{U}}\left(\mathrm{Bq} / \mathrm{m}^{3}\right) \times 1.2\left(\mathrm{~m}^{3} / \mathrm{h}\right) \times 2000 \mathrm{~h} \times 5.7 \times 10^{-6}(\mathrm{~Sv} / \mathrm{Bq})$

Table (2) represents the annual effective dose due the inhalation of $\mathrm{U}-238, \mathrm{E}_{\mathrm{U}}$, received by the workers at RREs project. The value of $\mathrm{E}_{\mathrm{U}}(\mathrm{mSv})$ at the different stages of the chemical extraction is lower than the recommended limit, $20(\mathrm{mSv})$. However, technical enhancement is needed to lower the dispersion of the dust into the air of REEs hanger. This may accomplished by automation of the feeding of the reactor. This justifies the enclosure of the whole process. 
Total annual effective dose:-

The total annual effective dose received by the workers at REEs project is calculated as follows:

$\mathbf{E}_{\text {total }}=\mathbf{E}_{\mathrm{ext}}+\mathbf{E}_{\mathrm{Rn}}+\mathbf{E}_{\mathrm{Tn}}+\mathbf{E}_{\mathrm{U}}$

Table (2) represents that total annual effective dose $E_{\text {total }}(\mathrm{mSv} / \mathrm{y})$ at the different stages of extraction of REEs from monazite. It's clear that the total annual effective doses are within limits since the dose limit for occupational is 20 $(\mathrm{mSv} / \mathrm{y})$. The majority of the effective dose comes from the uranium content in the air dust. Also, concentration of U-content at the digestion stage leads to a higher value of the total annual effective dose $\mathrm{E}_{\text {total }}$ at this stage.

\section{Monazite processing by adding $\mathrm{BaCl}:-$}

Table (3) and (4) represent the external and internal exposure through different stages of REEs extraction from monazite and the total annual effective dose by adding $\mathrm{BaCl}$ through digestion stage which precipitates radium from the solution. It is expected to minimize the dose rates through the reminder stages. However, all types of exposures are much below the recommended limits. On one hand the radioactive source has a limited total specific activity of $55636\left(\mathrm{~Bq} / \mathrm{m}^{3}\right)$ [24], or a total activity of $5.6 \times 10^{5}(\mathrm{~Bq})$. On the other hand the hanger of the project at NMA is wide enough and has good natural ventilation. This fades the probable effect of adding $\mathrm{BaCl}$ at the stage of digestion.

\section{Background:-}

Table (5) compares the background of the types of exposure at the REEs project and some laboratories of NMA. it is clear from the table that the background of each type of exposure is at the REEs project is higher than the corresponding type of background at the regular laboratories, comparing table (1) and (5), it is clear that the background concentrations of radon and thoron gases and the background gamma effective dose rate are almost similar to that due to the studied process on $10 \mathrm{~kg}$ of monazite. This is due to the REEs project contain some findings that belong to other previous separation patches. Besides, contamination due to the separation process is accumulated on the surfaces of the used instruments and wall and floor of the REEs hanger.

Table (1): Gamma equivalent dose rate $\mathrm{H}(\mu \mathrm{Sv} / \mathrm{h})$; concentrations of radon gas $\mathrm{C}_{\mathrm{Rn}}\left(\mathrm{Bq} / \mathrm{m}^{3}\right)$; thoron gas $\mathrm{C}_{\mathrm{Tn}}$ $\left(\mathrm{Bq} / \mathrm{m}^{3}\right)$; uranium concentrations $\mathrm{C}_{\mathrm{U}}\left(\mathrm{Bq} / \mathrm{m}^{3}\right)$ at the different stages of flow sheet.

\begin{tabular}{|c|c|c|c|c|c|}
\hline No. & stages & $\begin{array}{c}\mathrm{H} \\
(\mu \mathrm{Sv} / \mathrm{h})\end{array}$ & $\begin{array}{c}\mathrm{C}_{\mathrm{Rn}} \\
\left(\mathrm{Bq} / \mathrm{m}^{3}\right)\end{array}$ & $\begin{array}{c}\mathrm{C}_{\mathrm{Tn}} \\
\left(\mathrm{Bq} / \mathrm{m}^{3}\right)\end{array}$ & $\begin{array}{c}\mathrm{C}_{\mathrm{U}} \\
\left(\mathrm{Bq} / \mathrm{m}^{3}\right)\end{array}$ \\
\hline 1 & (heating)+sample preparation (weighting) & 0.21 & 14.40 & 56.88 & 0.29 \\
\hline 2 & Digestion & 0.11 & 8.56 & 56.88 & 0.88 \\
\hline 3 & Adjust of pH and pumping the filtrate & 0.15 & 5.86 & 114.7 & $\mathrm{BDL}$ \\
\hline 4 & filtration of thorium & 0.12 & 0.81 & 100.5 & - \\
\hline 5 & Adjust of pH & 0.18 & 8.56 & 70.98 & - \\
\hline 6 & washing & 0.11 & 14.15 & 56.88 & - \\
\hline
\end{tabular}

$\mathrm{BDL}=$ below detection limit; - = not measured

Table (2): Annual effective dose received by the workers from gammma rays $\mathrm{E}_{\mathrm{ext}}(\mathrm{mSv})$; radon gas $\mathrm{E}_{\mathrm{Rn}}(\mathrm{mSv})$; thoron gas $\mathrm{E}_{\mathrm{Tn}}(\mathrm{mSv})$; uranium concentrations, $\mathrm{E}_{\mathrm{U}}(\mathrm{mSv})$, total internal effective dose $\mathrm{E}_{\text {int }}(\mathrm{mSv})$; and total annual effective dose $\mathrm{E}_{\text {total }}(\mathrm{mSv})$.

\begin{tabular}{|c|c|c|c|c|c|c|c|}
\hline $\begin{array}{c}\text { stage } \\
\text { no }\end{array}$ & stages & $\begin{array}{c}\mathrm{E}_{\text {ext }} \\
(\mathrm{mSv})\end{array}$ & $\begin{array}{c}\mathrm{E}_{\mathrm{Rn}} \\
(\mathrm{mSv})\end{array}$ & $\begin{array}{c}\mathrm{E}_{\mathrm{Tn}} \\
(\mathrm{mSv})\end{array}$ & $\begin{array}{c}\mathrm{E}_{\mathrm{U}} \\
(\mathrm{mSv})\end{array}$ & $\begin{array}{c}\mathrm{E}_{\text {int }} \\
(\mathrm{mSv})\end{array}$ & $\begin{array}{c}\mathrm{E}_{\text {total }} \\
(\mathrm{mSv})\end{array}$ \\
\hline 1 & $\begin{array}{c}\text { (heating) sample preparation } \\
\text { (weighting) }\end{array}$ & 0.42 & 0.10 & 0.14 & 3.97 & 4.21 & 4.63 \\
\hline 2 & Digestion & 0.22 & 0.06 & 0.14 & 12.04 & 12.24 & 12.46 \\
\hline 3 & Adjust of pH and pumping the filtrate & 0.29 & 0.04 & 0.28 & 0.00 & 0.32 & 0.61 \\
\hline 4 & filtration of thorium & 0.24 & 0.01 & 0.24 & - & 0.25 & 0.49 \\
\hline 5 & Adjust of pH & 0.36 & 0.06 & 0.17 & - & 0.23 & 0.59 \\
\hline 6 & washing & 0.22 & 0.10 & 0.14 & - & 0.24 & 0.46 \\
\hline & average & 0.29 & 0.06 & 0.18 & 5.34 & 2.92 & 3.21 \\
\hline
\end{tabular}

Table (3): Gamma equivalent dose rate $\mathrm{H}(\mu \mathrm{Sv} / \mathrm{h})$; concentrations of radon gas $\mathrm{C}_{\mathrm{Rn}}\left(\mathrm{Bq} / \mathrm{m}^{3}\right)$; thoron gas $\mathrm{C}_{\mathrm{Tn}}\left(\mathrm{Bq} / \mathrm{m}^{3}\right)$; uranium concentrations $\mathrm{C}_{\mathrm{U}}\left(\mathrm{Bq} / \mathrm{m}^{3}\right)$ at the different stages of flow sheet with adding $\mathrm{BaCl}$ at the digestion stage. 


\begin{tabular}{|c|c|c|c|c|c|}
\hline stage no & stages of processing & $\begin{array}{c}\mathrm{H} \\
(\mu \mathrm{Sv} / \mathrm{h})\end{array}$ & $\begin{array}{c}\mathrm{C}_{\mathrm{Rn}} \\
\left(\mathrm{Bq} / \mathrm{m}^{3}\right)\end{array}$ & $\begin{array}{c}\mathrm{C}_{\mathrm{Tn}} \\
(\mathrm{Bq} / \mathrm{m} 3)\end{array}$ & $\begin{array}{c}\mathrm{C}_{\mathrm{U}} \\
\left(\mathrm{Bq} / \mathrm{m}^{3}\right)\end{array}$ \\
\hline 1 & (heating)+sample preparation (weighting) & 0.11 & 9.10 & 66.51 & 0.29 \\
\hline 2 & Digestion with adding BaCl & 0.11 & 8.90 & 58.36 & 0.88 \\
\hline 3 & Adjust of pH and pumping the filtrate & 0.11 & 10.42 & 62.07 & $\mathrm{BDL}$ \\
\hline 4 & filtration of thorium & 0.12 & 3.82 & 94.00 & - \\
\hline 5 & Adjust of pH & 0.31 & 10.81 & 58.27 & - \\
\hline 6 & washing & 0.17 & 11.32 & 62.54 & - \\
\hline & average & 0.16 & 9.06 & 66.96 & 0.39 \\
\hline
\end{tabular}

Table (4): Gammma rays $\mathrm{E}_{\mathrm{ex}}(\mathrm{mSv})$; annual effective dose received by the workers from Radon gas $\mathrm{E}_{\mathrm{Rn}}(\mathrm{mSv})$; thoron gas $\mathrm{E}_{\mathrm{Tn}}(\mathrm{mSv}) ;$;otal internal effective dose $\mathrm{E}_{\text {int }}(\mathrm{mSv})$; and total annual effective dose $\mathrm{E}_{\text {total }}(\mathrm{mSv})$.

\begin{tabular}{|c|c|c|c|c|c|c|c|}
\hline $\begin{array}{c}\text { stage } \\
\text { no }\end{array}$ & stages & $\begin{array}{c}\mathrm{E}_{\mathrm{ext}} \\
(\mathrm{mSv})\end{array}$ & $\begin{array}{c}\mathrm{E}_{\mathrm{Rn}} \\
(\mathrm{mSv})\end{array}$ & $\begin{array}{c}\mathrm{E}_{\mathrm{Tn}} \\
(\mathrm{mSv})\end{array}$ & $\begin{array}{c}\mathrm{E}_{\mathrm{U}} \\
(\mathrm{mSv})\end{array}$ & $\begin{array}{c}\mathrm{E}_{\text {int }} \\
(\mathrm{mSv})\end{array}$ & $\begin{array}{c}\mathrm{E}_{\text {total }} \\
(\mathrm{mSV})\end{array}$ \\
\hline 1 & $\begin{array}{c}\text { (heating)+sample preparation } \\
\text { (weighting) }\end{array}$ & 0.22 & 0.07 & 0.16 & 3.97 & 4.20 & 4.42 \\
\hline 2 & Digestion with adding BaCl & 0.22 & 0.06 & 0.14 & 12.04 & 12.24 & 12.46 \\
\hline 3 & $\begin{array}{c}\text { Adjust of pH and pumping the } \\
\text { filterate }\end{array}$ & 0.22 & 0.08 & 0.15 & 0.00 & 0.23 & 0.45 \\
\hline 4 & filtration of thorium & 0.24 & 0.03 & 0.23 & - & 0.26 & 0.50 \\
\hline 5 & Adjust of pH & 0.62 & 0.08 & 0.14 & - & 0.22 & 0.84 \\
\hline 6 & Washing & 0.34 & 0.08 & 0.15 & - & 0.23 & 0.57 \\
\hline & average & 0.31 & 0.07 & 0.16 & 5.34 & 2.90 & 3.21 \\
\hline
\end{tabular}

Table (5): Background concentrations of radon and thoron gases $\left(\mathrm{Bq} / \mathrm{m}^{3}\right)$ at the REEs project and other laboratories at NMA. Background value of the annual effective dose rate $(\mu \mathrm{Sv} / \mathrm{h})$ is represented.

\begin{tabular}{|c|c|c|}
\hline Type & At REEs & Labs \\
\hline $\mathrm{C}_{\mathrm{Rn}}\left(\mathrm{Bq} / \mathrm{m}^{3}\right)$ & 8.72 & 1.57 \\
\hline $\mathrm{C}_{\mathrm{Tn}}\left(\mathrm{Bq} / \mathrm{m}^{3}\right)$ & 76.14 & 6.29 \\
\hline $\mathrm{E} \gamma(\mu \mathrm{Sv} / \mathrm{h})$ & 0.11 & 0.07 \\
\hline
\end{tabular}

\section{Recommendation:-}

The relative high background at the hanger of the REEs project at the nuclear materials authority, NMA, Egypt, strongly recommends the periodic clearance of the instruments, walls and the floor.

\section{Conclusion:-}

Using $10 \mathrm{~kg}$ of monazite concentrate (50\% purity) to separate REES added an average total effective dose of 3.21 (mSv/y) to the environment of the hanger of REEs project. The wide dimension of the REEs hanger along with the good ventilation faded the effect of adding $\mathrm{BaCl}$ at the stage of digestion such that no difference appeared in the total effective dose received by the workers at the REEs. It is recommended to make technical enhancement to reduce the U-content in the air of the REEs hanger.

\section{References:-}

1. IAEA (2011): "Radiation protection and norm residue management in the production of rare earths from thorium containing mineral" International Atomic Energy Agency.safety series No.( 68), Viena.

2. Pillai.P.M.B. "Naturally Occurring Radioactive Materials (NORM) in the Extraction and Processing of Rare Earths" Officer in Charge, Health Physics Unit, Indian Rare Earths Ltd Udyogamandal P.O, Kerala, India.

3. Polednak, A. P.; Stehney, A. F.; Lucas, H. F. (1983): "Mortality Among Male -Workers at a Thoriumprocessing Plant "Health Physics. 44 (S1) pp.239-251.

4. Costa-Ribeiro.C. C.; Barcinski, M. A. ; Figueiredo, N.; Franca, E. Penna; Lobao, N.; Krieger, H.(1975) " Radiobiological Aspects and Radiation Levels Associated With the Milling of Monazite Sand" Health Physics. 28, (3), pp. 225-231.

5. Haridasan.P.P; Pillai.P.M.B; Tripathi.R.M and Pauranik.V.D (2008): "Occupational radiation exposure due to norm in a rare-earth compounds production facility" Oxford Journals Science \& Mathematics Radiation Protection Dosimetry Volume 131, Issue 2 Pp. 217-221. 
6. CHAPUIS, A.M., (1993): Résidus miniers, Commission pour les questions scientifiques et techniques relatives à la gestion des déchets radioactifs auprès du conseil scientifique du CEA.

7. IAEA (2011): Radiation protection and safety of radiation sources international basic safety standards. International Atomic Energy Agency.safety series No. (115), Viena.

8. IAEA, (1976): Manual on Radiological Safety in Uranium and Thorium Mines and Mills. International Atomic Energy Agency, IAEA, Vienna, Safety Series 43.

9. ICRP (2007): The 2007 Recommendations of the International Commission on Radiological Protection. International Commission on Radiological Protection. ICRP Publication 103.

10. WHO, 1986. Indoor Air Quality Research: Report on a WHO Meeting, 27-31 August 1984, Stockholm. World Health Organization, Copenhagen.

11. IARC, 1988: Monographs on the Evaluation of Carcinogenic Risk to Humans: Man-made Fibres and Radon. IARC 43. International Agency for Research on Cancer, Lyon.

12. ICRP, (1993): against radon-222 at home and at work. International Commission on Radiological Protection. Protection Annals of the ICRP 22(2). ICRP Publication 6. Pergamon Press, Oxford, 1993.

13. UNSCESR, (1988): Sources, Effects and Risks of Ionizing Radiation. United Nations Scientific Committee on the Effects of Atomic Radiation, 1988 Report to the General Assembly, with annexes. United Nations sales publication. E.88.IX.7. United Nations, New York.

14. UNSCESR, (1993): Sources and Effects of Ionizing Radiation. United Nations Scientific Committee on the Effects of Atomic Radiation, Report to the General Assembly. With scientific annexes. United Nations sales publication E.94.IX.2. United Nations, New York.

15. UNSCEAR (2000)): United Nation scientific Committee on the effect of atomic radiation,Sources and Effects of Ionizing Radiation, 2000 Report to the General Assembly, with Scientific Annexes, Vol. 1: Sources, UN, New York (2000).

16. ICRP, (1994): Human Respiratory Tract Model for Radiological Protection, Publication 66, Pergamon Press, Oxford and New York.

17. ICRP, (1979): Limits for Intakes of Radionuclides by Workers: Part 1, Publication 30, Pergamon Press, Oxford and New York.

18. IAEA (1996): International Basic Safety Standards for Protection against Ionizing Radiation and for the Safety of Radiation Sources, International Atomic Energy Agency, IAEA, Safety Series No. 115, IAEA, Vienna (1996).

19. ICRP, (1989): Age-dependent Doses to Members of the Public from Intake of Radionuclides: Part 1, Publication 56, Pergamon Press, Oxford and New York.

20. ICRP, (1993): Age-dependent Doses to Members of the Public from Intake of Radionuclides: Part 2, Ingestion Dose Coefficients, Publication 67, Pergamon Press, Oxford and New York.

21. ICRP, (1995): Age-dependent Doses to Members of the Public from Intake of Radionuclides: Part 3, Ingestion Dose Coefficients, Publication 69, Pergamon Press, Oxford and New York.

22. ICRP, (1995): Age-dependent Doses to Members of the Public from Intake of Radionuclides: Part 4, Inhalation Dose Coefficients, Publication 71, Pergamon Press, Oxford and New York.

23. IAEA, (1999): Assessment of Occupational Exposure Due to Intakes of Radionuclides, Safety Standards Series No. RS-G-1.2, IAEA, Vienna.

24. Nasr, Amal, S. (2012): Environmental and biophysical consideration of radioactive elements in processes of separation and concentration of black sand products in Egypt, M.Sc. Thesis, faculty of Science, Cairo University. 